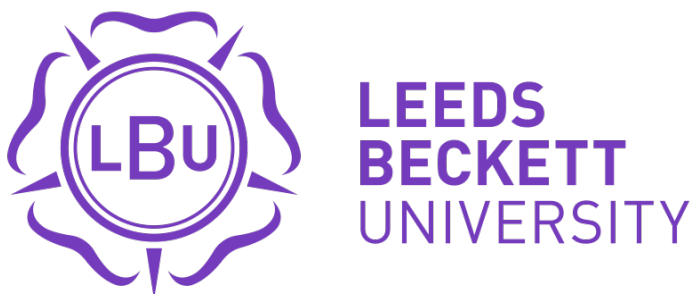

Citation:

Gregson, J (2015) Marxism Lost and Found: Alasdair Maclntyre and the Contemporary Debate. International Critical Thought, 5 (2). 211 - 225. ISSN 2159-8312 DOI: https://doi.org/10.1080/21598282.2015.1032323

Link to Leeds Beckett Repository record:

https://eprints.leedsbeckett.ac.uk/id/eprint/1373/

Document Version:

Article (Accepted Version)

The aim of the Leeds Beckett Repository is to provide open access to our research, as required by funder policies and permitted by publishers and copyright law.

The Leeds Beckett repository holds a wide range of publications, each of which has been checked for copyright and the relevant embargo period has been applied by the Research Services team.

We operate on a standard take-down policy. If you are the author or publisher of an output and you would like it removed from the repository, please contact us and we will investigate on a case-by-case basis.

Each thesis in the repository has been cleared where necessary by the author for third party copyright. If you would like a thesis to be removed from the repository or believe there is an issue with copyright, please contact us on openaccess@leedsbeckett.ac.uk and we will investigate on a case-by-case basis. 
Marxism Lost and Found: Alasdair MacIntyre and the Contemporary Debate

By

John Gregson

\author{
John Gregson \\ Leeds, United Kingdom \\ Email: J.Gregson@leedsbeckett.ac.uk \\ Tel: 01138120000 \\ Mailing Address: \\ Leeds Beckett University \\ Calverley Building 905 \\ City Campus, Leeds \\ LS1 3HE, United Kingdom
}

Affiliation: Department of Social, Psychological and Communication Sciences, Leeds Beckett University, 


\title{
Marxism Lost and Found: Alasdair MacIntyre and the Contemporary Debate
}

\author{
John Gregson* \\ Department of Social, Psychological and Communication Sciences, Leeds Beckett University, Leeds, United \\ Kingdom
}

\begin{abstract}
This paper examines the changing nature of debates that focus on the philosophy of Alasdair MacIntyre. Whilst outlining the history of MacIntyre's engagement with Marxism and some of his key ideas, it argues that it is only recently that such debates have begun to rightfully recognise the continued relevance of Marxism to such discussions. I note that crucial aspects of MacIntyre's politics and philosophy, particularly his opposition to capitalism, are now integral to the contemporary debate which helps in generating a shared vision of radical politics. Nevertheless, I point out that key disagreements still remain as to the role of Marxism within such debates, the validity of MacIntyre's critique of Marxism, as well as the potentially problematic post-Marxist practice that MacIntyre advocates in After Virtue and beyond.
\end{abstract}

Keywords: MacIntyre; Marxism; ethics; liberalism; capitalism

\section{Introduction}

I begin by examining trends in the discussion of the work of Alasdair MacIntyre, with regards to the significance of Marxism to such debates. The paper initially outlines some key themes that have remained central to MacIntyre and were originally developed within Marxist parameters in his attempt to theorize an ethical alternative to both Liberalism and Stalinism. This serves to highlight how peculiar it might appear that something that was so important to MacIntyre for so long was, at least for the most part, largely ignored in the debates focusing on one of the world's foremost moral philosophers. I move on to examine why this situation might have occurred and outline a number of factors that came together to create this unfortunate situation. I argue that this was unfortunate for two reasons. Firstly, in following Kelvin Knight and others, I point out that the majority of MacIntyrean debate involved a mischaracterisation of MacIntyre's position which created wholly inaccurate and unhelpful parameters within such debates. Secondly, and relatedly, I argue that this created a situation where the most valuable aspects of MacIntyre's radical politics tended to be given a rightwing inflection that suppressed or jettisoned his anti-state and anti-capitalist politics. I suggest, as MacIntyre himself does, that it is not possible to accept aspects of MacIntyre's philosophy whilst rejecting his politics.

I move on to show that the contemporary MacIntyrean debate has addressed these failings and, thanks largely to Kelvin Knight, now recognises the centrality of Marxism to MacIntyre's mature position and the value of his radical politics. I argue that this renewed recognition of the importance of Marxism means that such debates are far more valuable as they engage from a similar perspective that shares the same standpoint and many of the same aims, allowing for a deeper level of discussion that shares much with the methodological form of immanent critique. Finally, I examine one of the key questions that concern the contemporary debate, specifically with regards to the role and value of Marxism and MacIntyre's post-Marxist conception of revolutionary practice that aims to move beyond the perceived limitations of Marxism. I conclude by asserting that many of the answers to questions such as these remain open, which will ensure the vibrancy of the debate for the foreseeable future.

\section{The Forgotten MacIntyre}

MacIntyre's first substantial work was a 1953 book entitled Marxism: An Interpretation, written when he was 23 years old. This book signalled the beginning of a complex and often stormy engagement with Marxism, and within Marxist organizations, that culminated with his resignation from the board of International Socialism in 1968 when he essentially ceased to be a Marxist. MacIntyre became a prominent figure within The First New Left in Britain in the 1950's, notably in the journal The New Reasoner (formerly The Reasoner) edited by John Saville and Edward Thompson. Within the pages of this "most remarkable of journals" (MacIntyre 2007, xvii), key intellectual figures on the Left debated the role and nature of socialist humanism in opposition to the "orthodox" Marxism of the Soviet Union.

MacIntyre's search was for a third moral position that could escape the inadequacies of both Stalinism's rejection of morality —as Thompson (1957) had also argued - and the liberal position from which the critique of Stalinism tended to come. For MacIntyre, this liberal critique was not only morally incoherent, but unfortunately, generally reflective of the condition of modern society $(1958,91-92)$. This first diagnosis of the moral incoherence of modernity was what MacIntyre would go on to develop into a far more sustained and devastating critique of liberal modernity and its associated ethical theories in 1981's After Virtue (2007). Unlike in After Virtue, however, within Notes from the Moral Wilderness $(1958,1959)$, MacIntyre's potential solution

\footnotetext{
*Email: J.Gregson@ leedsbeckett.ac.uk
} 
to the problem of the modern moral wilderness lay within Marxism. MacIntyre argued that, properly understood, Marxism provided an interpretation of history that placed human agency at its centre and was fundamentally opposed to the mechanistic dogma of Stalinism that — quite falsely—placed sole primacy on the economic base over the superstructure $(1958,98-99)$. For MacIntyre, and others such as Thompson $(1961,38)$ who borrowed from MacIntyre's understanding of the relationship between base and superstructure, a genuinely Marxist conceptualisation of this relationship provided the "humanist" side to "socialist humanism." Dissolving the rigid separation between its two aspects provided the potential for understanding politics, ethics and human agency in a way that rejected Socialism conceived as a form of economic determinism that blindly shaped the lives of those who lived within its societies. MacIntyre also understood that this humanist interpretation needed to be understood in the wider context of Marx's theory of human nature which was integral to it. When MacIntyre $(1958,99)$ stated that "human nature is not a pious addendum to his [Marx's] economic analysis," he was simultaneously making both a particular criticism of the Stalinist method and a more general criticism of the Kantian dualist method of viewing particular aspects of a totality, such as the economic, in isolation from their relationships with its other aspects. MacIntyre argued that both the Stalinist and the Liberal positions are guilty of assigning this primacy to the economic base, in terms of their tendency to subordinate Marx's concept of human nature to the primacy of the economy. The Stalinist implementation of such an approach meant that human nature and human action were regarded as causally and rigidly determined by the economic foundations of a particular society $(1958,98-100)$.

For MacIntyre, to over-emphasise the importance of Marx's purely economic theories and to abstract them from his overall theory of human nature meant missing the crucial way that Capitalism appropriates and develops this human nature. MacIntyre argued that within capitalist society, unlike in previous modes of production, it becomes possible to reach the full potential of our human essence because of two preconditions that only now could be satisfied - one material and one social. MacIntyre observed that, materially, the type of person that we are able to become has been historically restricted by the type of society within which we lived and the problems of scarcity and primitive technologies that have characterised such societies. He states that:

\footnotetext{
Under capitalism the growth of production makes it possible for man to re-appropriate his own nature, for actual human beings to realize the richness of human possibility. But not only is the growth of production necessary. The experience of human equality and unity that is bred in industrial working-class life is equally a pre-condition of overcoming men's alienation from this and from themselves. And from the standpoint of that life and its possibilities we can see each previous stage in history as a particular form of approximation to a climax which it is now possible to approach directly. $(1959,95)$
}

The second precondition is a social one characterized by the dominant conditions of industrialization that are prevalent within the capitalist system. The key relationship under capitalism is between worker and capitalist and it is as a consequence of this relationship that the possibility for humanity to reach its potential finally becomes apparent. As MacIntyre states, "the emergence of human nature is something to be comprehended only in terms of the history of the class struggle" $(1959,94)$. This specific nature of Capitalism, MacIntyre argued, creates the social conditions through which human beings can reach their potential and which might provide a coherent ethical framework for human life (95).

\section{Aristotle without Marx}

The next decade saw a number of other significant contributions from MacIntyre, both from within the more intellectual-driven New Left and from revolutionary socialist organisations such as International Socialism (a recent edited collection by Blackledge and Davidson [2008] is invaluable in republishing many of these). Of particular note here are 1960's "Freedom and Revolution" (1960a, originally published in Labour Review) and "Breaking the Chains of Reason" (1960b), originally published in E. P. Thompson's edited collection Out of Apathy. Yet MacIntyre's project of developing this third moral position from within Marxist parameters, as well as his wider relationship with Marxism, was already coming to an end before he officially left International Socialism in 1968. MacIntyre's most substantial work in this period, 1966's A Short History of Ethics (1991a), gave the clearest indication as to the increasing distance between MacIntyre and Marxism. Crucially, MacIntyre had come to hold the view that there could now be "no appeal to human nature as a neutral standard" (1991a, 268). This rejection of a general theory of human nature meant that the claim within Notes from the Moral Wilderness that Marxism might be able to provide such a standard had now been rejected by MacIntyre. If the basis of such a claim - rooted as it was in a theory of human nature-had gone, so too had the possibility of Marxism providing any coherent alternative to Liberalism. In this context, it is not surprising that the conclusions of A Short History of Ethics are so negative or, as one commentator put it, devastating for ethics (Lutz 2004, 25). MacIntyre himself had not completely ruled out some alternative moral and social practice, lest we would all be doomed to what he called Nietzsche's "moral solipsism" (1991a, 268). Yet MacIntyre later argued that he perhaps should have given Nietzsche the final word here, as he had not yet developed a coherent alternative of social practices that might offer an alternative conception of ethics (1991b, 261). MacIntyre's 
break with Marxism was both theoretical and practical. Practically, MacIntyre moved to America around 1970 and seemingly severed links with those old comrades with whom he had been closely involved for a number of years. Peter Sedgwick, a former comrade of MacIntyre's in International Socialism, argued MacIntyre's intellectual genesis was characterised by a common pattern of warm comradeship followed by recoil and disengagement which would seem to fit this move (Sedgwick 1982, 10). Regarding MacIntyre's relationship to Marxist theory, one commentator went so far as to label the period leading up to the publication of After Virtue as that of "Aristotle without Marx" in MacIntyre's career (Burns 2010, 24). Whilst MacIntyre has disputed the assertion that he abandoned Marx completely in this period, there is certainly logic to this claim as MacIntyre (2010a, 174) recently admitted that, during this period, his discussions with "even the most insightful Marxists were becoming barren" and that he had to find "quite other means for carrying enquiry forward."

MacIntyre's often stormy relationship with Marxism (or more particularly Marxists) has deeper roots than simply his rejection and disengagement from Marxism and his former colleagues. As Blackledge and Davidson explain, MacIntyre's decision to publish in CIA (Central Intelligence Agency)-sponsored, right-wing journals whilst still in International Socialism resulted in considerable embarrassment and anger from his comrades. According to Chris Harman, International Socialism's leading member Tony Cliff was privately furious with MacIntyre for publishing in Encounter. Similarly, the editorial board of New Left Review-figures such as Robin Blackburn, Perry Anderson and Tariq Ali-held a longstanding animosity towards MacIntyre for such dubious publishing decisions (Blackledge and Davidson 2008b, xvi). It was also easy to see why Blackburn argued that MacIntyre specialised in "hatchet jobs" on respected figures of the Left. In the space of a single paragraph, whilst writing a review of Brian Behan's book for International Socialism in 1965 ("the best man who was a revolutionary socialist in Britain in the last twenty five years"), MacIntyre used this short space to openly criticize Marxists "who were good at repeating ritual formulas parrot-fashion" and those who had "not so much swallowed the formulas as been swallowed up by them." MacIntyre finished the paragraph with a reference to what he called the "officially licensed revolutionaries of the mock left" $(1965,29)$. Similarly, in Marcuse, the titular subject has "a taste for pretentious nostrums described in inflated language" (1970, 86), whilst Raya Dunayevskya is described as having an "entirely idealised view of [the working] class" (1958a, 43) and a review of C. Wright Mills is often far less that favourable (1962). In this context, it is perhaps not surprising that Tariq Ali, in a critique of the First New Left, urged us to read Notes - but only for pure amusement value (Blackledge and Davidson 2008b, xvii), whilst Perry Anderson (1980, 108) rather disparagingly dismissed MacIntyre as a former Marxist who "ended up on the pages of Encounter and Survey."

\section{After Virtue, after Marx?}

The 1970s signalled the beginning of a project by MacIntyre that aimed to provide an alternative to Nietzsche's nihilism that the MacIntyre of 1966 was not. The result of this search for a moral theory that might challenge Nietzsche was a landmark work in moral philosophy: After Virtue (2007), published in 1981, and widely regarded as MacIntyre's Magnus Opus. Perhaps only John Rawls's A Theory of Justice (1999) had a greater impact on late twentieth century political philosophy - a discipline which, at least partially as a result of Rawls's work, had become synonymous with liberalism and almost inseparable from it. The sheer scope and originality of MacIntyre's work was undoubtedly impressive and also particularly prescient in that it offered an understanding of the modern world and ethics that was fundamentally opposed to liberalism. Of course, the powerful challenge to liberalism in After Virtue meant that it was also seen as a direct counter to Rawls's seminal work and it was not uncommon to see both texts feature heavily on political philosophy degrees as well as, crucially, generating a great deal of debate between liberals and communitarians - the latter of which claimed MacIntyre as a key ally in defence of their political philosophy (Kymlicka 2002, 209; Mulhall and Swift, 1996).

It is not difficult to see why MacIntyre was labelled as a communitarian by those keen to draw him to their cause. Central to After Virtue is its pessimistic diagnosis of our moral condition which, argues MacIntyre, can only be overcome through "the construction of local forms of community" which are able to save us from the "new dark ages which are already upon us" (2007, 263). Given the strong critique of liberalism that runs through After Virtue, combined with this seeming endorsement of some kind of community-based politics, it might have seen logical to associate MacIntyre with the communitarian position. However, the communitarian badge pinned on MacIntyre was completely inaccurate and this misconception created a peculiar situation where the majority of MacIntyrean debate was misrepresentative of MacIntyre's position or had simply misunderstood it (Knight 1998a, 290). MacIntyre has himself gone a long way to dispel such myths of association with Communitarianism, levelling two rather emphatic criticisms at it. Firstly, he has pointed out that he sees "no value in community as such" and secondly-the crucial rejection-that he regards Communitarianism as compatible with the values and political institutions of liberalism that he has long since rejected (MacIntyre 2007, xvi). Neil Davidson has argued that "MacIntyre's current audience tends to be uninterested and consequently remains in ignorance" of much of his early, Marxist period (Davidson 2010, 87). Reinforcing this 
point, other collections that focus on MacIntyre's thought tend to either largely ignore or underestimate the significance of MacIntyre's early Marxism (Murphy 2003; Horton and Mendus 1994).

After Virtue, certainly on a cursory inspection, continued the pattern in MacIntyre's intellectual career of distancing himself from both Marxist theory and from his Marxist past. There are scarcely two pages specifically dedicated to Marxism in After Virtue and these are essentially only to reject it. And if some might find it slightly unfair to classify MacIntyre's treatment of Marxism here, as one critic did, as "breezy and glib" (Adamson 1985, 1), there was certainly no indication that After Virtue was written by a man with a long history of serious engagement with Marxism. Undoubtedly, the seemingly pessimistic conclusions concerning the possibilities for moral resistance to modernity as seen in After Virtue also did not sit well with those on the revolutionary Left. Even the minority of Marxists who recognise the power and value in MacIntyre's work tend to be highly critical of the seemingly pessimistic political conclusions that After Virtue entails (Blackledge 2008a, 2008b; Callinicos 2010; Harman 2009). As Sedgwick notes, it would be hard for those on the revolutionary Left to endorse MacIntyre's politics in which—or so it was perceived by some — political activism was not a virtue (Sedgwick 1982, 14).

A peculiar situation was created, therefore, where one of, if not the most important influences on MacIntyre's thought was all but ignored (with the notable exception of Kelvin Knight, whom I return to shortly) within the boundaries of much MacIntyrean debate. Yet this apparent lack of knowledge of MacIntyre's Marxist past was not the most critical failing of such debates. Perhaps most importantly, the radical, anti-capitalist themes that continued to inform MacIntyre's work in After Virtue and beyond tended to be brushed over or ignored within the context of the liberal vs. communitarian debate. Similarly, the breadth and scope of After Virtue, almost inevitably, attracted admirers from a myriad of competing political and philosophical positions. This had the unfortunate effect that MacIntyre was, and still is, regarded as an intellectual hero by those that share nothing with his politics or are even actively opposed to them. The fundamental problem with the jettisoning of MacIntyre's politics from his philosophy is that it attempts to separate aspects of MacIntyrean thought that logically cannot be separated. MacIntyre's work needs to be understood as he himself understands it - as a totality in which the ethical and political are not separately identifiable realms. In the preface to After Virtue, MacIntyre (2007, xvii) states that: "This book emerged from extended reflection upon the inadequacies of my own earlier work in moral philosophy and from a growing dissatisfaction with the conception of "moral philosophy" as an independent and isolable area of enquiry."

A brief but telling example of what MacIntyre means by this can be seen in a recent exchange with a Law Professor, Robert T. Miller. Miller calls himself an admirer of MacIntyre's moral philosophy but strongly rejects his political economy. Specifically, Miller wholeheartedly rejects Marxian economics and MacIntyre's critique of capitalism, yet he maintains that MacIntyre is one of his intellectual heroes. Miller (2011) argues that "a foundational attack on capitalism is an attack on the material well-being of the human race and especially an attack on the poor, who have been most helped by capitalism." Clearly, MacIntyre would disagree with this, but what is of most interest is the inconsistency he points to in Miller's position. The essence of MacIntyre's reply is that it is incoherent to discard his political economy whilst attempting to leave his moral philosophy intact. The central thesis of After Virtue, MacIntyre notes, is the "corrosive effect of the individualism of modernity on the tradition of the virtues." If one is to accept this analysis of modernity, one is also compelled to accept the premises on which it is based as these are inseparable from the thesis itself. Those premises are, of course, that it is the present social and economic order that has created the situation which MacIntyre diagnoses in After Virtue and beyond. Therefore, suggests MacIntyre, one must either accept the totality of this argument (including its premises) or reject it outright (2011). Miller, therefore, is logically compelled to do the latter but, illogically, chooses instead to pick and choose this or that fragment of After Virtue, whilst discarding others, in a manner that fails to grasp the central importance of interdependence between ethics and politics that After Virtue rests upon.

Interestingly, the assertion that ethics and politics need to be understood interdependently is often also sadly lacking in wider debates. Both Raymond Geuss and Alain Badiou have identified fundamental weaknesses with what Bourg $(2007,13)$ has called "the ethical turn" within contemporary philosophy. Geuss (2008, 6) argues that a fundamental weakness in much contemporary ethical debate is that it treats ethics as "a separate discipline ... which has its own distinctive subject-matter and forms of argument." The problem with this separation of the ethical is that when ethics is treated as an abstract phenomenon, in splendid isolation from other disciplines, debates themselves must also remain on a purely theoretical and abstract level. It is unsurprising that this type of ethics is characterised by Badiou (2001, 4-5) as being "compatible with the selfserving egoism of the west" because it fails to provide a potential standpoint from which to practically challenge the established order. If ethics is politically impotent, ethical discussion can do nothing except leave everything as it is. And as Eagleton $(1996,325)$ has stated: "If you see ethics and politics as separate spheres . . you are likely to end up denigrating the political and idealising the ethical." The idealisation of the ethical at the expense of the political, if anything, reflected much MacIntyrean commentary, in that it held a conception of the relationship between ethics and politics that saw the former as being distinct from the latter. 


\section{Redrawing the Boundaries}

As we have seen then, there were a number of factors that combined to ensure that MacIntyrean debates tended to ignore MacIntyre's relationship to Marxism. Firstly, MacIntyre himself distanced himself from Marxism (even if it remained an influence on him) and there was very little engagement with Marxism by MacIntyre from the 1970s until the 1990s. Secondly, those on the Left who were perhaps politically closer to MacIntyre (at least at one time) did not, as a rule, engage with After Virtue or any of MacIntyre's post-Marxist philosophy. This lack of engagement was either due to After Virtue's - arguably_-pessimistic conclusions which did not sit well with the far Left, or perhaps because of lingering resentment at MacIntyre's critiques of well-respected figures within Marxism and his questionable publishing decisions. Thirdly, the common mischaracterisation of MacIntyre as a communitarian meant that After Virtue was used in political debates that shared little with MacIntyre's own politics and perhaps even less with Marxism. The political distance between MacIntyre and most of those engaged in the MacIntyrean debates was perhaps reflective of a wider tendency within such debates to treat his moral philosophy - appealing even to the non-radical — as being detachable from, what was for many, his less palatable, radical political and economic critique of modernity.

An almost lone voice during the 1990's, beyond the de-radicalized, communitarian and conservative nature of MacIntyrean debate, was that of Kelvin Knight. Contrary to prevalent opinion, Knight understood MacIntyre's contemporary political philosophy as continuing a project began in his Marxist period (Knight 2010, 13, 21). Knight made the significant point that Marx remained a central figure, even in MacIntyre's "mature" thought, and his work was central in shifting the parameters of the contemporary MacIntyrean debate to include this assertion. Jeffery Nicholas (2014) has also highlighted the continuing relationship between MacIntyre and Marxism. Nicholas emphasises the important link between MacIntyre's Christianity and his Marxism, stating that the political commitments of MacIntyre's Marxism cannot be separated from his Christianity. Perhaps Nicholas's most important argument here is his view that as MacIntyre recovered his Christianity through Aristotle, he also recovered his Marxism in which the concept of alienation remained central to his critique of the world (Nicholas 2014, 236). Similarly to Knight, Nicholas views the contemporary MacIntyre as continuing a project abandoned by Marx after 1848, as evidenced in MacIntyre's important discussion of Marx in The Theses on Feuerbach: A Road Not Taken (1994).

Crucially, what lent Knight's interpretation of MacIntyre credibility was that, unlike in the firm rejection of the communitarian interpretation of this work, MacIntyre himself agreed that Knight's interpretation was a far more accurate characterisation of his position (MacIntyre 2010b). Knight must be understood as being a key figure in bringing Marx back into the MacIntyrean debate. One might go even further and suggest that Knight was central in bringing MacIntyre himself back into debates concerning Marxism and his relationship to it. This re-emergence of Marx was evident in the increasing tendency in recent years of MacIntyre engaging more often (and perhaps more generously) with Marxism - either to clarify his changing relationship to Marxism, to emphasise its continuing importance to him, or to re-state the critique that he continues to make of it (MacIntyre 2008, 2010a, 2010b). MacIntyre's recent valuable contributions have often been posited as a direct response to contributions and criticisms made from within the contemporary debate, serving to highlight the close relationship between the two.

Knight's key article, originally published in 1996, was certainly a turning pointing in MacIntyrean debate, as was his edited collection two years later, which itself included Notes and, in a lengthy introduction, made clear how important Marxism was to MacIntyre (Knight 1998a, 1998b). A number of important publications followed (Knight 2007; Blackledge and Davidson 2008a; Blackledge and Knight 2010; Nicholas 2012) and Knight and others founded the International Society of MacIntyrean Enquiry (ISME), inaugurated at a 2007 conference in London which MacIntyre himself attended and that served to crystallise some of the key parameters of this emerging MacIntyrean debate. Central to ISME were a number of important assertions concerning MacIntyrean thought. These included the recognition of MacIntyre's opposition to the injustices of capitalism, the powerful contribution MacIntyre has made to radical politics and his radical opposition to liberalism - all of which were viewed through the prism of an Aristotelian, Thomistic view of human flourishing to which the influence of Marxism is still significant (ISME 2007). As a result, a growing number of books, edited collections, journal articles and symposiums have been published that have contributed to a debate that conceptualises MacIntyre far more accurately in terms of his radicalism, as opposed to the conservative communitarian label that was misguidedly thrust upon him.

One reason why this recognition of the centrality of Marxism to MacIntyre was important was that it created the possibility for MacIntyrean debate to take on the methodological form of immanent critique. Central to the approach of immanent critique is the assertion that a critique or refutation of a particular argument is much more powerful when it engages with its target on its own terms. Hegel recognised the strength of immanent critique when he stated that: 
the refutation must not come from outside, that is, it must not proceed from assumptions lying outside the system and in question and inconsistent with it ... the defect is a defect only for him who starts from the requirements and demands based on those assumptions. (Hegel in McCarney 1990, 11)

In relation to MacIntyrean debate, it follows that criticisms aimed at MacIntyre from an externalised position, a polar opposite political standpoint for example, essentially do nothing in terms of generating valuable debate. It is the academic equivalent of a shouting-match or of name-calling. It is not to say that one side or another of the argument is necessarily wrong, rather that there can be nothing new or valuable generated by such exchanges and the criticisms that are generated from such positions are not, at least on this interpretation, telling ones. This is why the externalised critiques from those such as Miller, or the Communitarian, (at least as conceptualised by MacIntyre) debating with MacIntyre provide little in the way of politically positive contributions to such debates.

Immanent critique suggests that in order to critically engage on a deeper level with a subject, one must accept both certain parameters within that particular debate, as well as sharing certain aims and objectives that form a central part of it. This common ground, as McCarney points towards, is similar to what Adorno means when he argues that it "is not the ideas . . . but rather the claims . . . to have realized those ideas" (Adorno in McCarney 1990, 18) which is the aim of immanent critique. Shared aims and assumptions necessarily provide a more constructive element to such debates as all those engaged within them are essentially pulling in the same direction. Whilst there may be vigorous disagreement and numerous areas of contestation within such debates, the acceptance of certain parameters foster an environment of continued, positive engagement rather than negative withdrawal. The common acceptance of certain parameters does not suggest that such debates lack the critical edge of more fundamental disagreements. Indeed, it can be argued that the very opposite is true. What Hegel and Adorno's assertions show is that it is only from within what has been called the "sphere of immanence" (McCarney 1990, 21) that it becomes possible to provide genuine refutation. Key criticisms of both Marxism and MacIntyre's post-Marxism within such debates are better-equipped to understand the most significant strengths and weaknesses of each position than those which proceed from a position of externality.

\title{
6. Questions in the Contemporary Debate
}

The changing parameters of the contemporary MacIntyrean debate have been summed up accurately by Andri Bielskis who states:

\begin{abstract}
MacIntyre scholarship has consistently moved from a communitarian interpretation towards a far more accurate reception of his thought which can be broadly described as a revolutionary Thomism. This post-communitarian reading of Alasdair MacIntyre acknowledges the central importance of Marxism not only in the early, pre-1968 works of MacIntyre, but also seeks to show the centrality of Marxism in his mature work. (Bielskis 2010, 160; italics added)
\end{abstract}

This final remark is perhaps one of the most significant aspects to the contemporary MacIntyrean debate. The recognition of Marxism's centrality here ensures that, as it so often is, it is not dismissed without serious engagement or due process and those discussions tend to be of a constructively critical nature. The contemporary MacIntyrean debate recognises that the aims of both Marxists and MacIntyreans within such contemporary debates coincide in their belief in trying to "open a dialogue about the possibility of developing a virtuous political practice in the modern world ... of exploring the possibilities . . of leading a good life in and against a bad world" (Blackledge and Knight 2010, 3).

Nevertheless, significant differences remain as to the role and relevance of particular aspects of Marxism within such debates. Overall, perhaps the dominant tendency within such debates as to the role of Marxism can be summed up in the position of Kelvin Knight who views MacIntyre's post-Marxism as both building on, and-crucially-moving beyond Marxism. There is a general acceptance that MacIntyre's mature position addresses what are deemed as key weaknesses or failings in Marxism and consequently it provides a conception of revolutionary political practice that is superior to Marxism itself. This general logic-that MacIntyre's mature position moves beyond Marxism - also runs through the work of other contributors to these debates, such as Bielskis (2010) and Perreau-Saussine (2010), who tend to accept one aspect or another of the critique of Marxism which itself plays a key role in laying the foundations for MacIntyre's mature position.

There are two ways that this kind of logic can be (and has been) challenged within the parameters of such debates, both of which provide the space for continued valuable discussion as to the role of Marxism here. Firstly, there have been strong arguments to suggest that MacIntyre's critique of Marxism is built on a number of highly contested assumptions. These arguments that question the premises of MacIntyre's critique of Marxism can be traced back to an important point made shortly after the publication of After Virtue, in a review article by a one-time comrade of MacIntyre, Peter Sedgwick. Sedgwick (1982) argued that there was a tendency in MacIntyre's writings to imbue the characters in After Virtue's "ethical dance" (such as Marx) with characteristics that were only actually present when viewed in a certain "telling light" and presented in a very 
particular, one-sided manner. These contested interpretations of such characters meant, for Sedgwick, that MacIntyre had been overly-hasty in sweeping the likes of Marx under the carpet in order to make them fit, perhaps too conveniently, into the (politically and ethically inadequate) roles that he had assigned to them. What MacIntyre had essentially done in After Virtue, was to conflate the Marxist with the Stalinist in a way that ran counter to the very different roles that he saw these two characters playing in much earlier works such as Notes From the Moral Wilderness. More recently, this type of criticism has been more fully developed into immanent critique by those such as Blackledge, who has argued on numerous occasions that, whilst there is a rational kernel of truth to MacIntyre's critique of Marxism, MacIntyre himself once understood that, in certain forms, Marxism was not susceptible to the types of criticism of its ethics and politics that he now associates with all forms of Marxism (Blackledge 2005, 2008a, 2008b). Consequently, these contrasting views of MacIntyre's critique of Marxism have created some important and vigorous exchanges within the parameters of such debates which look well set to continue.

The second way that MacIntyre's post-Marxist position has been challenged involves the examination of the revolutionary Thomism or revolutionary Aristotelianism which MacIntyre understands as providing an alternate form of revolutionary practice to the inadequacies of Marxism. Perhaps the central question here is just how revolutionary is this revolutionary Aristotelianism? Or, to put it slightly differently, just how capable is it of developing the kind of virtuous political practice that is necessary in providing the possibility for leading a "good life" in a "bad world"? It is in this area that MacIntyre's post-Marxism from After Virtue onwards is, for some, at its most questionable.

Those such as Noponen (2010), Bielskis (2010) and Knight (2010) have all defended MacIntyre's revolutionary Aristotelianism or Thomism on the grounds of its revolutionary credentials or its practical application to the problem of virtuous political practice. MacIntyre himself has argued that what makes his postMarxist position revolutionary is that it represents a break with those who speak and act from the standpoint of civil society (1994, 232). Noponen and Bielskis, in particular, have gone further, citing the practicality and relevance of MacIntyre's conception of political practice and how it has positively shaped specific political movements, whilst Knight $(2010,20)$ has also argued it is the juxtaposition of institutions to practices that can essentially create a platform from which to defend practices such as education and medicine against the degenerative influence of the modern, bureaucratic institutions that so often damage them.

Jeffery Nicholas (2008) has developed a valuable discussion of the potentially revolutionary role played by what he argues are MacIntyrean-type practices - specifically the Roman Catholic practice of Eucharist and the game Dungeons and Dragons. Through a discussion of ideology and ideology critique, Nicholas argues that such practices can promote the type of critical thinking that is able to resist the dominant ideologies of commodity fetishism and scientism. The key questions here, as Nicholas $(2008,101)$ correctly identifies, are "Can something as simple as DnD (Dungeons and Dragons) really provide moments of resistance to such dominant ideas as commodity fetishism and scientism? What allows players to question the ideology in the game and, therefore, in their own lives?" Nicholas's argument is that such practices as DnD embody the kind of virtues and standards of reason that stand in opposition to key aspects of commodity fetishism and scientismindividualism, determinism, alienated human relationships, for example. Nicholas argues that the type of substantive reason developed within such practices can provide the point of departure for resistance not just inside but also outside the practice in the everyday lives of the participants $(2008,103)$.

Through engagement in such practices, Nicholas's argument, therefore, dovetails with both Knight and MacIntyre in that it recognises the potentially revolutionary (in the MacIntyrean sense) nature of such practices and, if such practices as DnD can be extrapolated to the wider experience of everyday life and a critical world view, the kinds of criticisms, discussed shortly, that argue that MacIntyre's conception of practices is too particularistic and marginalised, can be positively addressed. However, questions still remain concerning the role and revolutionary ability of such practices. One might argue that such practices as DnD are themselves symptomatic of the alienation experienced in people's everyday lives, that they represent a retreat from, not an engagement with, the contemporary capitalist order. Perhaps, such practices as $\mathrm{DnD}$ are an example of a compartmentalized world in which the DnD player leaves his more virtuous alter-ego at, for example, the door of the marketing or management company that he or she works for? Whether it is possible to generalize the experiences of such practices into a coherent, political movement beyond the reach of such practices themselves and that might break through the ideological veils of capitalist society remains an important area for debate.

It is the strength of MacIntyre's conception of practices that, for those such as Knight and Nicholas, it can potentially provide the possibility of "a politics in the Aristotelian tradition . . . to defend the rationality, ideals, creativity and cooperative care for common goods of practices against institutional corruption and managerial manipulation" (Knight 2010, 19). Concretely, argues Knight $(2010,19)$, "it is . . in collective defence of the goods and rationalities of practices against those of institutions that the bases for a politics in the Aristotelian tradition are now to be found." Those perhaps more generally critical of MacIntyre's post-Marxist position, such as Blackledge (2008b, 7), still recognise that what MacIntyre posits as a form of resistance may be utopian but it is nevertheless a "concrete utopia." This type of utopianism, as David Harvey notes, is a "utopianism of 
process" rather than a "utopianism of form" which he distinguishes as a "principled way in which to talk about the need to regulate human relationships and our collective endeavours so as to achieve a particular set of goals" and is therefore much more than the "self-negating" utopianism of form (Harvey 1996, 333).

Despite, as we have seen, the often pessimistic tone that is apparent in works such as After Virtue, MacIntyre's post-Marxism position is nevertheless one that makes a concrete contribution to ethical, anticapitalist politics. MacIntyre $(1997,235)$ has continued to argue that "not only have I never offered remedies for the condition of liberal modernity, it has been part of my case that there are no remedies." Yet this seeming pessimism is not to say that MacIntyre's political practice shares the same levels of extreme pessimism as, for example, a Marcuse or an Adorno. Certain political, social and economic struggles continue to receive support from MacIntyre and, he argues, can begin to exemplify those types of practices which, at a certain level, can begin to at least envisage a break with the dominant standpoint of civil society. MacIntyre (2006) continues to support such struggles that are:

engaged in by members of some rank and file trade union movements, of some tenants' associations, of the disability movement, of a variety of farming, fishing, and trading cooperatives, and by some feminist groups, and on the other by those who work within schools, hospitals, a variety of industrial and financial workplaces, laboratories, theatres, and universities in order to make of these, so far as possible, scenes of resistance to the dominant ideology and the dominant social order.

Interestingly, Jeffery Nicholas has recently attempted to combine a MacIntyrean notion of tradition with the critical theory of The Frankfurt School despite, as we have seen, MacIntyre's strong reservations with theorists such as Marcuse. Nicholas's Book is particularly prescient as it represents an attempt to address MacIntyre's view that it is of vital importance for Marxists and Thomistic Aristotelians to communicate with each other (Nicholas 2012, 200). Nicholas develops a conception of substantive reason-crucial to a critical theory of society - that builds on the insights of the Frankfurt School and addresses their weaknesses through incorporating the MacIntyrean concept of reason-constituted tradition. Interestingly, this marriage of Thomistic Aristotelianism and Ideology Critique, unlike Blackledge and Knight's focus on practices, sees tradition as the "fundamental unifying concept" (Nicholas 2012, 85) in such a task, therefore it certainly provides a fresh avenue of debate within MacIntyrean studies.

Yet serious questions still remain within such debates, particularly with regards to the inclusivity of MacIntyrean practice, the role of political activism and the nature of the resistance to civil society that MacIntyre theorizes. One of the key areas of contestation can be understood more clearly when we relay MacIntyre's point that it is only within the type of practices that are "socially marginalised" within capitalist society that we can begin to envisage radically different forms of social relationships and institutions aimed at the achievement of the "common good" (MacIntyre 2010a, 176; 1994, 233). Yet, as both Callinicos (2010) and McMylor (1993) have suggested, the problem here is that resistance becomes marginalised, necessarily particularistic and MacIntyre is forced to use examples from highly specific practices because of the subordinated nature of such practices within capitalist society (McMylor 1993, 151). The consequence of the marginalisation of such specific practices is that, for some, to call MacIntyrean practice revolutionary is a misnomer, as the term revolutionary implies the kind of comprehensive social transformation (Callinicos 2010, 44) that MacIntyrean practice cannot even imagine. This has led to strong reservations with MacIntyre's radical politics, particularly from the Marxist left (those who are at least prepared to engage with him), the response of which can be summed up by Harman (2009) who argued:

It all reads to me like a call for hippy communes without hippies. If MacIntyre means by "morality" what he used to mean by it, such communities cannot be a moral response to what the system is doing to humanity in the 21 st century.

Similar points are made by both Blackledge (2008b) and Davidson (2010), and all these echo a much earlier reservation with MacIntyre's radical politics from Schneewind who pointed towards the "profoundly pessimistic" and "self-defeating" qualities of After Virtue, sceptical of a localized form of resistance that would have "those of us who are clever and prosperous . . . foregather with groups of like-minded friends to cultivate our own gardens, while the weeds grow and the litter collects in the public places" (Schneewind 1982, 662-63).

Commenting on MacIntyre's assertion that "I do not see any prospects of overthrowing the dominant social order . . . perhaps it can be outlived; and even if it cannot be overthrown, it ought to be rejected" (MacIntyre in Davidson 2010, 98); Davidson notes that "the difficulty is that it looks increasingly likely that the dominant social order may not allow us the luxury of outliving it." Furthermore, as Davidson rightly notes, poverty, war and starvation are not the only pressing problems - the very real concern of "environmental catastrophe" necessitates, if anything, a more pressing and vigorous response to capitalism than ever before as its disastrous effects become ever more apparent (Davidson 2010, 98). 


\section{Conclusion}

Throughout his career, MacIntyre can be seen to have built on Lukács claim that "the task [of philosophy] is to discover the principles by means of which it becomes possible in the first place for an 'ought' to modify existence" (Lukács 1967, 161). And whilst the "principle by means of which it becomes possible" has changed significantly for MacIntyre, the importance of regarding ethics and politics as inseparable has remained central - and this understanding of the interrelationship between ethics and politics is a highly significant point to take from debates concerning MacIntyre's relationship to Marxism. It is precisely because MacIntyrean philosophy retains this close relationship between theory and practice that it becomes all the more important to question and debate what it puts in the place of Marxism. For if it was developed to remain purely in the abstract then questions as to its political value would consequently be irrelevant. The same, of course, can be said of Marxism. It is because MacIntyre's understanding of Marxism was so powerful (and that his post-Marxist position was subsequently built on a rejection of that Marxism) that it demands to be taken seriously. And to take it seriously means to evaluate its possibilities as an ethical—political—project. If one holds that Capitalism is unjust, oppressive and exploitative, then one must also hold that something else is, or can be, more desirable. Yet if one is to reject those forces immanent within capitalism that provide the best possibility of realizing that something else then, effectively, one is accepting the inevitability of capitalism.

This rejection of the revolutionary potential of the working class, at least on one interpretation, can sum up the difficulties of replacing a theory of liberation such as Marxism with the (arguably) more particularistic, pessimistic MacIntyrean version. MacIntyre himself, in following Goldmann, once understood socialism as a "wager" on the working class. Furthermore, he $(1964,314)$ argued that "the wager of action is unavoidable" and those who do not make the "bet" on the working class are implicitly accepting the "tragic vision" of capitalism. It is perhaps this tragic vision that still haunts MacIntyre's post-Marxism more than anything else. To evaluate the ethical and political possibilities within Marxism and MacIntyre's post-Marxism brings us back to Adorno's point: the value does not necessarily lie in questioning the aims of those post-Marxist theories such as MacIntyre's - the value lies in questioning the possibility of realizing those aims. It is such questions that ensure the continued vibrancy of the contemporary MacIntyrean debate - and they do so within parameters which rightfully recognise the continued relevance of Marxism to such debates.

\section{Notes on Contributor}

John Gregson is Senior Lecturer in criminology at Leeds Beckett University. His main research interests include the philosophy of Alasdair MacIntyre, Marxism and other theories of justice, and radical criminology. He is currently writing a paper on the problem of justification in Marx \& MacIntyre, as well as a book on MacIntyre's ethics and politics.

\section{References}

Adamson, W. L. 1985. Marx and the Disillusionment of Marxism. Berkeley: University of California Press.

Anderson, P. 1980. Arguments within English Marxism. London: Verso.

Badiou, A. 2001. Ethics: An Essay on the Understanding of Evil. London: Verso.

Bielskis, A. 2010. "Alasdair MacIntyre and the Lithuanian New Left.” In Virtue and Politics: Alasdair MacIntyre's Revolutionary Aristotelianism, edited by P. Blackledge and K. Knight, 160-69. Notre Dame, Indiana: University of Notre Dame Press.

Blackledge, P. 2005. "Freedom, Desire and Revolution: Alasdair MacIntyre's Early Marxist Ethics." History of Political Thought XXVI (4): 696-720.

Blackledge, P. 2008a. “Alasdair MacIntyre's Contribution to Marxism: A Road Not Taken.” Analyse \& Kritik 30 (1): $215-$ 28 .

Blackledge, P. 2008b. “Alasdair MacIntyre: Social Practices, Marxism and Ethical Anti-Capitalism.” Political Studies 57 (4): 866-84.

Blackledge, P., and N. Davidson, eds. 2008a. Alasdair MacIntyre's Engagement with Marxism: Selected Writings 19531974. Boston: Brill.

Blackledge, P., and N. Davidson. 2008b. "Introduction: the Unknown Alasdair MacIntyre.” In Alasdair MacIntyre's Engagement with Marxism: Selected Writings 1953-1974, edited by P. Blackledge and N. Davidson, xiii-1. Boston: Brill

Blackledge, P., and K. Knight. 2010. "Introduction: Towards a Virtuous Politics.” In Virtue and Politics: Alasdair MacIntyre's Revolutionary Aristotelianism, edited by P. Blackledge and K. Knight, 3-7. Notre Dame, Indiana: University of Notre Dame Press

Bourg, J. 2007. From Revolution to Ethics. McGill: Queens University Press.

Burns, T. 2010. "Revolutionary Aristotelianism? The Political Thought of Aristotle, Marx and MacIntyre." In Virtue and Politics: Alasdair MacIntyre's Revolutionary Aristotelianism, edited by P. Blackledge and K. Knight, 22-32. Notre Dame, Indiana: University of Notre Dame Press.

Callinicos, A. 2010. "Two Cheers for Enlightenment Universalism." In Virtue and Politics: Alasdair MacIntyre's Revolutionary Aristotelianism, edited by P. Blackledge and K. Knight, 33-45. Notre Dame, Indiana: University of Notre Dame Press.

Davidson, N. 2010. “Alasdair MacIntyre and Trotskyism.” In Virtue and Politics: Alasdair MacIntyre's Revolutionary Aristotelianism, edited by P. Blackledge and K. Knight, 86-98. Notre Dame, Indiana: University of Notre Dame Press. 
Eagleton, T. 1996. The Illusions of Postmodernism. London: Blackwell.

Geuss, R. 2008. Philosophy and Real Politics. Princeton: Princeton University Press.

Harman, C. 2009. “MacIntyre's Forgotten Answers.” International Socialism 121 (January). http://www.isj.org.uk/index.php4?id=519\&issue=121.

Harvey, D. 1996. Justice, Nature and the Geography of Difference. Oxford: Blackwell.

Horton, J., and S. Mendus, eds. 1994. After MacIntyre. Cambridge: Polity Press.

ISME (International Society for MacIntyrean Enquiry) http://www.macintyreanenquiry.org.

Knight, K., ed. 1998a. The MacIntyre Reader. Cambridge: Polity Press.

Knight, K. 1998b. “Editor's Introduction.” In The MacIntyre Reader, edited by K. Knight, 1-30. Cambridge: Polity Press.

Knight, K. 2007. Aristotelian Philosophy: Ethics and Politics from Aristotle to Macintyre. Cambridge: Polity Press.

Knight, K. 2010. "Revolutionary Aristotelianism." In Virtue and Politics: Alasdair MacIntyre's Revolutionary Aristotelianis, edited by P. Blackledge and K. Knight, 13-21. Notre Dame, Indiana: University of Notre Dame Press.

Kymlicka, W. 2002. Contemporary Political Philosophy. Oxford: Oxford University Press.

Lukács, G. 1967. History and Class Consciousness. Boston: MIT Press.

Lutz, C. S. 2004. Tradition in the Ethics of Alasdair MacIntyre. Oxford: Lexington Books.

MacIntyre, A. 1953. Marxism: An Interpretation. London: SCM Press.

MacIntyre, A. 1958. "Notes from the Moral Wilderness-I." The New Reasoner 7 (Winter): 90-100. http://www.amielandmelburn.org.uk/collections/nr/index_frame.htm.

MacIntyre, A. 1958a. "The Algebra of the Revolution." Universities and Left Review 5 (Autumn): 59-60. Also available in: Alasdair MacIntyre's Engagement with Marxism: Selected Writings 1953-1974, edited by P. Blackledge and N. Davidson, 41-44. Boston: Brill.

MacIntyre, A. 1959. "Notes from the Moral Wilderness-II.” The New Reasoner 8 (Spring): 89-97. http://www.amielandmelburn.org.uk/collections/nr/index_frame.htm.

MacIntyre, A. 1960a. "Freedom and Revolution." Labour Review 5 (1): 19-24. Also available in Alasdair MacIntyre's Engagement with Marxism: Selected Writings 1953-1974, edited by P. Blackledge and N. Davidson, 123-34. Boston: Brill.

MacIntyre, A. 1960b. "Breaking the Chains of Reason." In Out of Apathy, edited by E.P.Thompson, 195-240. London: Stevens and Sons. Also available in Alasdair MacIntyre's Engagement with Marxism: Selected Writings 1953-74, edited by P. Blackledge and N. Davidson, 135-66. Boston: Brill.

MacIntyre, A. 1962. "C. Wright Mills.” International Socialism 9 (Summer): 221-23. Also available in Alasdair MacIntyre's Engagement with Marxism: Selected Writings 1953-1974, edited by P. Blackledge and N. Davidson, 24145. Boston: Brill.

MacIntyre, A. 1964. "Pascal and Marx: On Lucien Goldmann's Hidden God." Encounter 23 (4): 69-76. Also available in Alasdair MacIntyre's Engagement with Marxism: Selected Writings 1953-1974, edited by P. Blackledge and N. Davidson, 305-16. Boston: Brill.

MacIntyre, A. 1965. “Behan's Book.” International Socialism 21 (Summer): 29.

MacIntyre, A. 1970. Marcuse. London: Fontana.

MacIntyre, A. 1991a. A Short History of Ethics. London: Routledge.

MacIntyre, A. 1991b. "Interview with Giovanna Borradori." In The MacIntyre Reader, edited by K. Knight, 255-66. Cambridge: Polity Press.

MacIntyre, A. 1994. “The Theses on Feuerbach: A Road Not Taken.” In The MacIntyre Reader, edited by K. Knight, 255 66. Cambridge: Polity Press.

MacIntyre, A. 1997. "Politics, Philosophy and the Common Good." Studi Perugini, no. 3: 9-30. First published in English in The MacIntyre Reader, edited by K. Knight, 235-54. Cambridge: Polity Press.

MacIntyre, A. 2006. “Outside Ethics.” Notre Dame Philosophical Reviews. http://ndpr.nd.edu/review.cfm?id=5922.

MacIntyre, A. 2007. After Virtue. Third Edition. Notre Dame, Indiana: University of Notre Dame Press.

MacIntyre, A. 2008. "What More Needs to Be Said? A Beginning, Although Only a Beginning, at Saying It.” Analyse \& Kritik 30 (1): 261-82.

MacIntyre, A. 2010a. "Where We Were, Where We Are, Where We Need to Be." In Virtue and Politics: Alasdair MacIntyre's Revolutionary Aristotelianism, edited by P. Blackledge and K. Knight, 170-84. Notre Dame, Indiana: University of Notre Dame Press.

MacIntyre, A. 2010b. "How Aristotelianism Can Become Revolutionary." In Virtue and Politics: Alasdair MacIntyre's Revolutionary Aristotelianism, edited by P. Blackledge and K. Knight, 8-12. Notre Dame, Indiana: University of Notre Dame Press.

MacIntyre, A. 2011. "Response to Robert T. Miller.” First Things, April: 9.

http://www.firstthings.com/article/2011/04/letters.

McCarney, J. 1990. Social Theory and the Crises of Marxism. London: Verso.

McMylor, P. 1993. Alasdair MacIntyre: Critic of Modernity. London: Routledge.

Miller, R. T. 2011. "Waiting for St. Vladimir.” First Things, February: 37-43.

http://www.firstthings.com/article/2011/02/waiting-for-st-vladimir.

Mulhall, S., and A. Swift. 1996. Liberals and Communitarians. Oxford: Blackwell.

Murphy, M. C., ed. 2003. Alasdair MacIntyre. Cambridge: Cambridge University Press.

Nicholas, J. 2008. "Eucharist and Dragon Fighting as Resistance: Against Commodity Fetishism and Scientism." Philosophy of Management 17 (1): 93-106.

Nicholas, J. 2012. Reason, Tradition, and the Good. Notre Dame, Indiana: University of Notre Dame Press.

Nicholas, J. 2014. “Toward a Radical Integral Humanism: MacIntyre's Continuing Marxism.” Studia Philosophica Wratislaviensia, English Edition: 223-41. 
Noponen, N. 2010. “Alienation, Practices, and Human Nature: Marxist Critique in MacIntyre's Aristotelian Ethics.” In

Virtue and Politics: Alasdair MacIntyre's Revolutionary Aristotelianism, edited by P. Blackledge and K. Knight, 56-

63. Notre Dame, Indiana: University of Notre Dame Press.

Perreau-Saussine, E. 2010. "The Moral Critique of Stalinism." In Virtue and Politics: Alasdair MacIntyre's Revolutionary Aristotelianism, edited by P. Blackledge and K. Knight, 76-85. Notre Dame, Indiana: University of Notre Dame Press.

Rawls, J. 1999. A Theory of Justice. Revised Edition. Cambridge: Belknap.

Schneewind, J. B. 1982. "Virtue, Narrative, and Community: MacIntyre and Morality." The Journal of Philosophy 79 (11): 653-63. http://www.jstor.org/stable/2026540.

Sedgwick, P. 1982. "The Ethical Dance.” Socialist Register, no. 19: 259-67.

http://www.marxists.org/archive/sedgwick/1982/xx/macintyre.htm

Thompson, E.P. 1957. “An Epistle to the Philistines.” The New Reasoner 1: 105-43.

Thompson, E.P. 1961. “The Long Revolution-II.” The New Reasoner 10: 34-39. 